differentiating some species of unarmed cestodes. A combination of biological and molecular systematics is envisaged in costodo taxonomy, and this will force systematists into the field of electronic data-processing.

Dr J. L. Crites, in "Problems in Systematies of Parasitic Nematodes", considers that morphological descriptions are only a beginning and not an end in themselves, and with comparative data from other biological disciplines, when understood and correlated, will bring about a more integrated classification of the phylum Nematoda. An important problem in nematode taxonomy is the separate study of free-living nomatodes, those parasitic in plants and those parasitic in animals, and the barriers erected by these studies must be reduced.

Dr H. W. Manter, in "Problems in Systematics of Trematode Parasites", suggests that the prevailing difficulties in tromatodo systematics may be traced to incomplete knowledge, erroneous and meagre deseriptions and a widely scattered litcrature. 'To overcome these difficultios, the creation of centres for taxonomic studies is advocated. A platyhelminth classification at class level is presented with the consideration that, among other things, the Monogenea and Digenea (Trematoda) are distinct at this level. Classification of trematodes is reliable when derived from comparative morphology, life-histories, host-relations and geographical distribution.

"Problems in Systematics of Parasitic Protozoa", by Dr N. D. Levine, reviews problems of the relations of various groups, the systematic difficulties within each group, and the systematic position of certain enigmatic organisms placed in the Protozoa. Moreover, there is the question of whether the Protozoa (or Protista) represent a single phylum or a kingdom composed of several phyla. In the absence of life-history and other biological data, a taxonomy derived from numcrical procedure might be considered, but availablo information on structure is incomplete and would not give satisfactory results.

Dr Schrnidt concludes that ample evidence exists to show that confusion abounds in the systematies of every group of parasites, and that a satisfactory classification must embrace, not only sound morphological studies, but also data from ethological, biochemical, mathematical and other disciplines. To the practising systematist, however, tho essays also imply that non-morphological aspects in the taxonomy of parasites should be supplementary to comparative morphology. S. PRUDHOE

\title{
Obiluaries
}

\section{Lord Jackson of Burnley}

WILLIS JACKSON was born in Burnley in 1904 and died in London on February 17, 1970. After graduating from the University of Manchester, he completed a graduate apprenticeship at Motropolitan Vickers and entered technical education with successivo appointments at Bradford Technical College, Manchester College of 'T'echnology, and Exeter and The Queen's colleges, Oxford. He was appointed professor of clectrotechnics in the University of Manchestor in 1938 and quickly built up an active research team which made muny contributions to the tech. niques of mierowuve measurement. His leadership of this war-time research group brought him into elose contact with government establishments, in particular SRDE.

His appointment in 1946 as head of the department of electrical engineoring at Imperial College gave him the task of re-establishing the department after the war. He made sure that his students acquired a factual knowledge of elcetrical engineering as well as an appreciation of the problems they would encounter as practising engincers, and he created a strong research department.

In 1953 Jackson accepted an invitation to return to Metropolitan Vickers, by then AEI (Manchester), as director of research and education. As a member of tho Royal Commission on the Civil Service and through membership of the University Grants Committec, the Advisory Cornmittee on Scientific Policy and other similar bodies, he had begun to contributo to national technological policy. His chairmanship of the Committee on the Supply and Training of Technical Teachors, the Scientific Manpower Committee and its successor, the Committee on Manpower Resources for Science and Technology, led to the writing of many important official reports which continue to influence current developrnents.

Ho returned to Impcrial College in 1961 to lead a major expansion of the department of electrical engineering. From 1967, as pro rector, he gave the college the benefit of his wide experienco in formulating policies to meet the changing university secne.

He was elected to the Royal Society in 1953; a knighthood was conferred on him in 1958 and he was created a life peer in 1967. Throughout his carcer he worked enthusiastically for the Institution of Electrical Engineers and for the British Association for the Advancement of

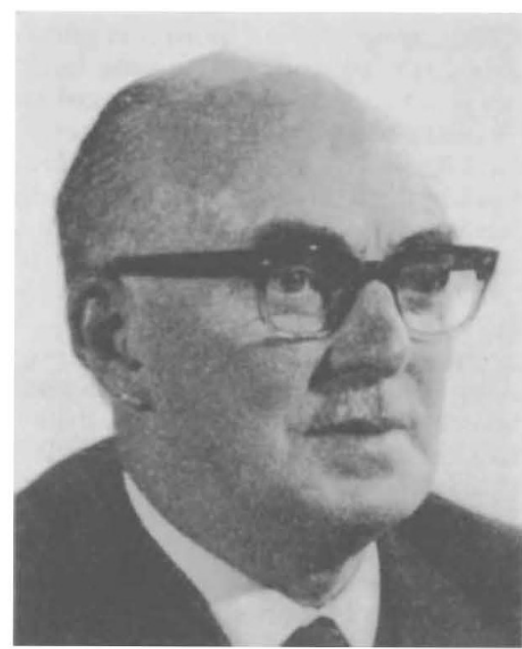

Lord Jackson of Burnley

Scicnce and both bodies recognized his services by electing him to the offico of president.

Two permanent tributes to him will remain. His interest in furthering technical education extended to overseas countries and he was responsible for the major British contribution from both industrial and government sources towards the foundation of the Indian Institute of Technology, New Delhi. In November 1969, the Institute of Manpower Studies was created, with Jackson as its founder president, to provide an independent research body to continuo and extend the work he had already begun on improving standards of the use of manpower.

In an inaugural lecture at Imperial College in 1962, Willis Jackson expressed a hope "for a quiet period of contemplation when I might seck to resolve some of the outstanding problems concerning the preparation of young men for careers in the engineering profession". His conscientious work for the bodies with which he was associated left him little time for quiet contemplation. There were so many of all ages who wanted his advice and help, and he never spared himself if he could be of service to others. 